\title{
From Inflation to Deflation: A Novel Experience for Hong Kong
}

To speed up its economic recovery, the Special Administrative Region is betting on a more intense economic integration with mainland China

\section{Peter Chiu}

\section{(2) OpenEdition}

\section{Journals}

Édition électronique

URL : http://journals.openedition.org/chinaperspectives/774

DOI : 10.4000/chinaperspectives. 774

ISSN : 1996-4617

Éditeur

Centre d'étude français sur la Chine contemporaine

Édition imprimée

Date de publication : 1 décembre 2003

ISSN : 2070-3449

\section{Référence électronique}

Peter Chiu, «From Inflation to Deflation: A Novel Experience for Hong Kong », China Perspectives [En ligne], 50 | november- december 2003, mis en ligne le 19 avril 2007, consulté le 21 décembre 2020. URL : http://journals.openedition.org/chinaperspectives/774 ; DOI : https://doi.org/10.4000/ chinaperspectives.774

Ce document a été généré automatiquement le 21 décembre 2020.

(c) All rights reserved 


\section{From Inflation to Deflation: A Novel Experience for Hong Kong}

To speed up its economic recovery, the Special Administrative Region is betting on a more intense economic integration with mainland China

\section{Peter Chiu}

1 Hong Kong's economy has gone from one of high inflation in the early 1990s into one of high deflation after the Asian financial crisis. Over the past five years, product and property prices, rents and wages have all been adjusted downwards. Both the investors and the government have been taken by surprise. Residential property prices have fallen $65 \%$. Many who bought properties at high prices are now suffering heavy capital losses. The government is facing decreasing revenues through a slowing-down of economic activities and has been suffering heavy budget deficits.

2 The effect of price level changes on the standard of living, in principle, should be neutral, assuming that a person has no assets or debts and relies solely on his income for survival. If his income and the prices of the goods he buys increase both by $10 \%$, he is no better or worse off. However such a case is rare. People usually possess assets such as property and incur debts such as mortgage loans. In times of inflation propertyowners gain as the value of their properties increase while their debts are a fixed amount. In times of deflation they lose as the value of their properties decreases while their debts are still a fixed amount.

Businessmen normally benefit in times of inflation. They find the prices of their products increasing faster than the salaries they pay to their employees. However the reverse is true in times of deflation and they suffer when the prices of their products falling faster than the salaries they have to pay out. This explains why businesses were generally profitable during the period of inflation of the early 1990 s and why so many firms have had to close down in period of the deflation following the Asian financial crisis.

4 Most wage earners suffer in times of inflation. But deflation gives them greater purchasing power. Provided they keep their jobs, they benefit from deflation. Inflation is usually accompanied by a rate of low unemployment and vice versa for deflation. 
While people complain about price increases when inflation rises they still have jobs and money to spend. Deflation brings job losses, despite falling prices.

Economic theory tells us that inflation can be restrained by a policy to allow the domestic currency to appreciate and deflation can be mitigated by a policy to allow the domestic currency to depreciate. However while the Hong Kong dollar is pegged to the US dollar at a fixed rate of US $\$ 1: H K \$ 7.8$, as it is currently under the linked rate system adopted since October $1983^{1}$, this will not occur in Hong Kong.

6 Economic theory also tells us that inflation can be restrained by a policy to reduce money supply through raising interest rates and deflation can be mitigated by a policy to increase money supply through a reduction in interest rates. However, under the linked rate system, interest rates in Hong Kong have to follow the interest rates in the United States. In other words, no discretionary monetary policy can be employed to tackle the problems of inflation and deflation in Hong Kong. However there is a selfadjustment mechanism inherent in the linked rate system. When there is inflation exports will fall. The fall in exports will lead to lower employment and lower inflation. When there is deflation exports will increase. The increase in exports will lead to higher employment and lower deflation.

7 In the United States and the United Kingdom, price levels have been quite stable since 1991 (see Figure 1). Both countries have been pursuing a policy to keep price levels stable through interest rate changes. When inflation is high, interest rates will rise. When inflation is low, interest rates will drop. At present the United States is experiencing slow economic growth accompanied by low inflation, and has, therefore, reduced its interest rates to an all-time low, i.e. a prime rate of $5 \%$. Recently there has also been the worry that the United States may fall into deflation.

Japan, China and Hong Kong have all experienced deflation to various extents in recent years. Both Japan and Hong Kong have suffered slow economic growth in recent years accompanied by deflation. However China also has been under deflationary pressure despite its rapid economic growth began. This phenomenon is usually explained by the fact that a substantial part of China's growth is generated by the government's spending on infrastructure, while demand in the market has remained sluggish.

Hong Kong experienced exceptionally high inflation in the early 1990s and exceptionally high deflation more recently. As mentioned earlier under the linked rate system, Hong Kong is unable to employ an exchange rate policy for the adjustment of its economy. Hence adjustment is mainly reflected in its price level, i.e. inflation and deflation.

10 The traditional explanation of inflation has been excess demand. When demand in the market is in excess of supply, prices are bid up. When the world economy experienced inflationary pressure in the 1970s and late 1980s, concerns now address more the suppression of demand. However the world economy is currently faced with the possibility of deflation. The demand explanation alone may not be adequate in explaining this.

11 Deflation is now regarded mainly as the result of excess supply. The rapid progress in information technology now extensively employed in the manufacturing and services sectors, has become a major factor for the fall in production costs and hence the increase in supply. Another explanation of deflation is the rapid increase in production as a result of some developing countries establishing a market economy, such as China 
and countries in Eastern Europe. These countries, endowed with abundant labour, are now able to pour out cheap products.

Under the linked rate system Hong Kong's inflation rate should theoretically follow that of the United States. If it does not, an adjustment process will take place which will eventually equalise the inflation rates in both. Suppose Hong Kong currently has a much higher inflation rate than the United States. Then Hong Kong goods will be less competitive than US goods in face of the outside world. Consequently Hong Kong is less able to obtain orders from other countries. The decrease in exports will have a contractionary effect on the economy. Eventually inflation will slow down.

When the linked rate system was set up it was expected that Hong Kong's inflation rate would follow that of the United States. However it turned out that the relationship only remains a theoretical long-run equilibrium relationship and in the short run there could be forces that would cause the inflation rate to deviate in the two places. If Hong Kong was sufficiently near to the United States and is producing goods similar to those produced in the United States, any deviation of inflation rates in the two places would activate the above adjustment process. However Hong Kong is geographically so far away from the United States and Hong Kong is producing goods so different from those produced in the United States. Furthermore Hong Kong is economically so much influenced by mainland China, which is experiencing a rapid rate of economic development. So there is no reason to expect that in the short term Hong Kong's rate of inflation should follow that in the United States.

Besides being located geographically far away from the United States, Hong Kong's economic structure is also different from that of the United States. The United States is a mature economy with a high level of technology, whereas Hong Kong is basically an entrepôt and a commercial centre. The factors that affect price level in the United States are not those affecting price levels in Hong Kong. A rise in oil prices is a major factor for inflation in the United States. But in Hong Kong this may be less important than an increase in demand for Hong Kong re-export and commercial services.

Inflation in Hong Kong in the early 1990s and the deflation after the Asian financial crisis should be viewed in the context of the linked rate system. In this paper we first review the causes of Hong Kong's high inflation in the early 1990s, then examine the causes of Hong Kong's deflation after the crisis. Finally we discuss how Hong Kong's economy adjusts to inflation and deflation under the linked rate system.

The causes of inflation in Hong KongStructural change

John Greenwood maintained that Hong Kong's high inflation in the early 1990s was due mainly to structural change that took place in Hong Kong. His argument runs as follows. After China adopted the open door policy Hong Kong gradually went through a structural change. Many manufacturers began to shift their production into mainland China. From 1991 to 2001, the number of employed persons in manufacturing has decreased by half whereas the number of employed persons in other industries, especially in finance, insurance, real estate and business services have increased rapidly (see Table 2). At the same time the rapid economic development of China has resulted in great demand for Hong Kong's commercial and financial services. This increased demand pushed up professional salaries (see Table 3) and rents of business premises. The inflation rate therefore started to rise $^{2}$.

Negative real interest rate 

regarded as another cause of Hong Kong's inflation (see Table 4) ${ }^{3}$. As mentioned earlier, under the linked rate system Hong Kong interest rates automatically follow US interest rates. Throughout the 1990s US interest rates stayed quite stable at around $5 \%$ per annum. As a result Hong Kong interest rates also stayed around this level.

For most of the early 1990s, real interest rates remained negative. People were encouraged to borrow money for investment. Most investments were in real assets such as properties, which in time of high inflation is a good hedge for inflation. When property prices increased, rent also increased (see Table 5). Increase in rents in turn forced up prices of outputs. So inflation that had been caused by structural change was made more severe under the condition of negative interest rates.

A weak Hong Kong dollar

19 The HK dollar link with the US dollar implies that when the US dollar depreciates against other currencies, the HK dollar also depreciates against other currencies. Since the mid-1980s until the mid-1990s the US dollar exchange value continued falling. In the mid-1980s the value of the US dollar against the Japanese Yen was US $\$ 1=¥ 260$. But by the mid-1990s this value had already fallen to around US $\$ 1=¥ 100$. The HK dollar also depreciated against the yen to the same extent. As Hong Kong had been importing substantially from Japan, the result was a rapid rise in import prices exerting inflationary pressure on Hong Kong.

There was strong criticism of the linked rate system and critics advocated linking the HK dollar to a basket of currencies instead of to the US dollar alone. However a study found that under the linked rate system pegging the Hong Kong dollar with a basket of currencies would require the government to alter the official exchange rate of 7.8 occasionally. This would undermine confidence in the linked rate system. As a result the Hong Kong government rejected the proposal and expressed its determination to continue linking the HK dollar with the US dollar'. 


\section{Evolution of inflation}

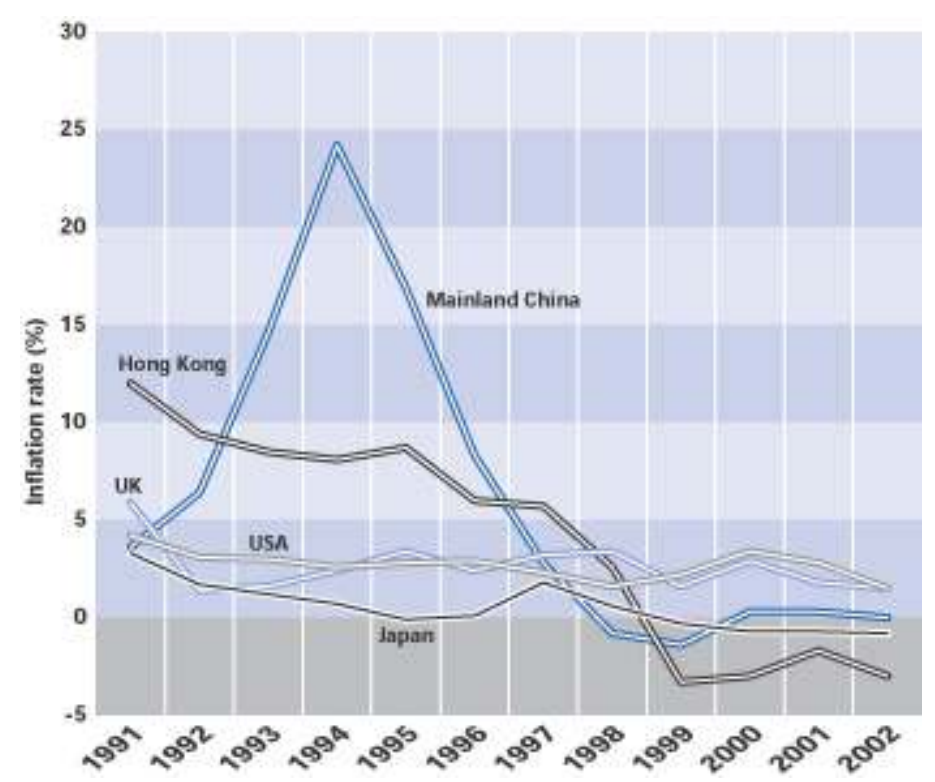

NB: Figures for 2002 are preliminary estimates.

Sources: International Financial Statistics, International Monetary Fund, various years. Hong Kong Annual Digest of Statistics, Census and Statistics Department, Hong Kong Special Administrative Region, various years. High government capital expenditures

21 Another cause of Hong Kong's inflation in the early 1990s was the high government capital expenditure on infrastructure projects such as the new airport at Chek Lap Kok. The airport was built on a piece of land reclaimed from the sea at Chek Lap Kok on Lantau Island. The cost of building the new airport amounted to nearly HK\$100 billion. Such a heavy injection of money into the economy inevitably caused inflationary pressure.

The policy of increasing capital expenditure was aimed at maintaining the confidence of investors within the economy. The 1997 issue whereby Hong Kong was to be returned to China caused a tremendous loss of confidence in the Hong Kong economy. The private sector was reluctant to invest resulting in huge capital outflow. With the successful signing of the Sino-British Agreement in 1984 confidence was restored. However the June Fourth event that took place in Peking in 1989 undermined confidence once again. To maintain confidence in and the economic growth of Hong Kong the government decided to construct the new airport at Chek Lap Kok .

The decision to construct a new airport did generate the expected effects. Confidence was restored. Investments increased with substantial capital inflow to the economy. Meanwhile Hong Kong also benefited from the rapid economic development of mainland China. The huge capital expenditure of the government thus became a cause of inflation rather than just a measure to maintain confidence and economic growth. With a rapidly increasing budget reserve brought about by the prosperous economy, the government was unable politically to resist the demand for increasing social welfare expenditure. Also government departments were expanded to provide improved services. In the 1980s government expenditure stood at around 18\% of GDP. But by the end of the 1990s this had already risen to around $23 \%$.

Low unemployment rate amid high inflation 

deflation. The relatively stronger value of the HK dollar as against its neighbouring countries results in reduced competitiveness of Hong Kong's exports in western countries. Hong Kong exporters face low demand from overseas buyers. Prices have to be lowered to cope with the reduced demand. Soon producers have to resort to cutting wages. So a process of price and cost cutting inaugurated the process of deflation. This process will continue until prices and wages have fallen enough to make Hong Kong goods competitive again. So deflation is an adjustment mechanism under the linked rate system when the currency is overvalued.

During the inflationary period of the early 1990s Hong Kong enjoyed real GDP growth on average at $5 \%$ per annum. Also unemployment rates were maintained on average at $2 \%$ per annum. The growth rate was considered as high for mature economies as a whole. The low unemployment rate was unmatched by other economies (see Figure 6).

It was at this time that the property bubble began to form. The high demand for both residential and business properties as a result of strong confidence in the economy and negative real interest rates pushed up property prices quickly. The restricted land supply of only 50 hectares per year as agreed by the Sino-British Agreement further pushed up property prices. Speculation then followed which eventually inflated the property bubble to its full size. When property prices reached their peak at end of 1997, they were almost ten times higher than in the mid-1980s. A small residential flat of 500 square feet commanded a price of around HK\$4 million, which was the highest by world standards.

During this period the unemployment rate stayed as low as $2 \%$ per annum on average. This level is practically full employment taking into account of people changing jobs and new graduates looking for jobs. There were in fact severe labour shortages during this period. People tended to change jobs frequently with higher salaries in the new jobs. Each week the South China Morning Post published nearly a hundred pages of job advertisements.

In July 1997 Hong Kong was handed back to China in a climate of high confidence and ungrounded economic prosperity. Hong Kong was as a hen that laid golden eggs. Backed by the fast developing mainland and being geographically located near to the mainland, Hong Kong's economic future was deemed incomparably brilliant.

The Asian financial crisis and the beginning of deflation

Asian region. South Korea and Indonesia were good examples: the financial systems of these two countries collapsed and their currencies fell drastically. Hong Kong was lucky enough not to be damaged seriously by the turmoil. The HK dollar was not affected due to its link with the US dollar. No damage was done to its financial system which had been well regulated and supervised. However a process of painful adjustment was inaugurated.

Under the linked rate system there is no possibility of a devaluation. If the HK dollar cannot be devalued, prices and wages have to adjust downwards. This is the process of One may ask why the government does not devalue the HK dollar. To answer this question we must examine why the linked rate system was set up initially. In 1982, then British Prime Minister Mrs. Thatcher went to Peking and talked with the Chinese leader Mr. Deng Xiaoping about the future of Hong Kong after the expiry of the lease of the New Territories, the northern part of Hong Kong. It was announced that China, besides 
refusing to extend the lease of the New Territories, was to reclaim Hong Kong in 1997. A confidence problem began to emerge. People began selling HK dollars for foreign currencies. In September 1983 the value of the HK dollar fell to nearly US\$1:HK\$10 from its normal level of HK\$1:HK\$6.5. To restore confidence in the HK dollar the government decided to adopt the linked rate system.

Since then the government has been convinced that the linked rate system is best suited for Hong Kong being a small economy without controls on capital movement. By linking the HK dollar with a stable hard currency, the US dollar, exchange stability for the HK dollar can be achieved. The system does not allow for devaluation and revaluation and depends solely on its automatic adjustment mechanism, i.e. adjustment through inflation and deflation. This mechanism inherent in the system could be relied upon to react to any external and internal economic shocks. If devaluation or revaluation would cause some disturbance. It would also lead to currency speculation and hence a lack of confidence again in the HK dollar. It is for this reason that the government is determined to maintain the 7.8 exchange rate $^{5}$.

Deflation as an adjustment

Deflation manifests itself mainly in three areas, i.e. prices of goods and services, property prices and rent, and wages. Prices of goods and services have been falling in the past few years. Negative inflation rates have occurred since 1999 (see Figure 6). Properties prices have adjusted downward since 1997, and rents too (see Table 5). Wage adjustments seem to lag behind rent and property price adjustments (see Table 3). This seems inconsistent with the general belief that wages in Hong Kong are falling. However we must bear in mind that in compiling these statistics no adjustment has been made to take account of employees being laid off who had to find other jobs with much lower salaries. The wage index only shows the change of wages for those who have remained in their jobs. This is a statistical loophole that should be filled.

As long as Hong Kong remains in the linked rate system, adjustment of the economy will have to be made through either inflation or deflation. Tony Latter, Deputy Chief Executive of the Hong Kong Monetary Authority (HKMA), at a conference jointly organised by the representative offices of Asian central banks in London and the Bank of England's Centre for Central Banking Studies, held at the Bank of England on June 12th 2001, made this clear6: "This adjustment process may imply either inflation or deflation, which may be at rates outside the bounds which would typically be set by an economy operating with inflation targeting. For instance, since the mid-1990s Hong Kong's 12-month rate of consumer price inflation has been as high as $10 \%$ and as low as minus $6 \%$. Although this is a much wider range than experienced in the United States, ... the peg itself serves a sort of insurance against excessive movements-of the nature of hyper-inflation or an intense spiral of deflation-because at some point competitiveness will be sufficiently curtailed or enhanced to halt the process".

Tony Latter however has the view that the linked rate system is best suited for Hong Kong for the following reasons. Hong Kong possesses the necessary conditions for the operation of the linked rate system, namely, sufficiently flexible costs and prices, a sound banking system, adequate fiscal discipline and the requisite foreign exchange reserves to back the monetary base. According to Tony Latter, deflation that emerges now in Hong Kong does not present a great problem, as it can be self-adjusted. Therefore there is no reason to abandon the linked rate system ${ }^{7}$.

The effect of economic integration between Hong Kong and mainland China 

China began its open-door policy. This has led to structural change in Hong Kong. It has also become a cause for Hong Kong's deflation ${ }^{8}$. As more Hong Kong people go to the mainland for business, there is a tendency among them to buy residential property there, especially in Shenzhen. Property prices in the mainland are very attractive to Hong Kong people. The average purchase price for a flat in Hong Kong can buy several flats of the same size in Shenzhen. Many people who are unable to buy flats in Hong Kong are buying flats in Shenzhen for retirement. Others buy them for holidays. The amount of money flowing into the mainland via property purchase is therefore substantial. This has been regarded as one of the reasons for the reduced demand for properties in Hong Kong and the resulting drop in property prices. effect on Hong Kong's prices. Prices of goods and services in the mainland are much lower than those in Hong Kong. As a result there is the tendency for Hong Kong people to go into China, especially into Shenzhen, during holidays and weekends. In long holiday periods such as Christmas, Chinese New Year and Easter, more than one million Hong Kong people cross the border. This has become one of the reasons for the low consumption within Hong Kong, and hits the retail industry hard. Unless retailers reduce their prices, there is little chance of competing with their counterparts in the mainland. However, this situation is expected to improve with the consent of the mainland government to allow more mainlanders to travel to Hong Kong.

\section{Evolution of employment in some sectors (thousand persons)}

\begin{tabular}{|c|c|c|c|c|c|c|c|c|c|c|c|}
\hline & 1991 & 1992 & 1991 & 1594 & 1995 & $19: 3$ & 1999 & 1989 & 1989 & 2000 & 2001 \\
\hline Manufacturing & 717.0 & $650 . \overline{5}$ & 594.0 & 562.6 & 5346 & 4899 & 4430 & 379.6 & 3539 & 333.7 & 3264 \\
\hline $\begin{array}{l}\text { Financing insurance. } \\
\text { real estate and tusiness }\end{array}$ & 222.1 & 231,9 & 289.2 & 356.7 & $341: 1$ & 3638 & 4051 & 4103 & 433.7 & 432.7 & 478.1 \\
\hline $\begin{array}{l}\text { Community, social } \\
\text { and personal services }\end{array}$ & 536.1 & 342.1 & 547.7 & 5sa.8 & 6099 & 6679 & 678? & Hesi & 7329 & 754.7 & 7989 \\
\hline
\end{tabular}

Source : Table 2.6, Hong Kong Annual Digest of Statistics, Census and Statistics Department, Hong Kong Special Administrative Region, 2002.

Economic integration between Hong Kong and mainland China also has a deflationary effect on Hong Kong's wages. As mentioned earlier, manufacturers have been shifting their production process into the mainland. This has put pressure on wages in the manufacturing sector. In recent years, there is also the tendency for Hong Kong's service providers to move part of their servicing process into mainland China. With the development of communications technology, it is now possible to relocate some parts of the servicing process to the mainland-some Hong Kong banks have moved their data processing units, while a number of mobile telephone companies have moved their customer service units. The consequence is the reduction of job opportunities in Hong Kong and a fall in wages.

The deflationary effects of economic integration between Hong Kong and the mainland are not a surprise. Economic theory has long pointed out this possibility. The Theorem of "Equalisation of Factor Prices" has predicted such a result 9 .

Joseph Yam, the Chief Executive of the Hong Kong Monetary Authority (HKMA) has also pointed out that deflation in Hong Kong is due to two factors, namely, the slow economic growth of the world economy and the increasing integration of the Hong

China Perspectives, 50 | november- december 2003 
Kong economy with that of the mainland ${ }^{10}$ : "The increasing integration, coupled to the starting point of huge discrepancies in prices and wages, consigns Hong Kong to deflation and the near mainland to inflation over time. This will in theory go on until the differentials have been arbitraged away to equilibrium levels, although in view of the significant differences under "one country, two systems", and the limitations in the flow of labour and capital, this does not necessarily mean price equalisation. In fact, the arbitrage process has already been operative for over twenty years, as the mainland embarked on the road of reform and liberalisation in earnest. It is just that the process has been accelerated in recent years."

41 Hong Kong's deflation is an adjustment process under the linked rate system for the regaining of lost competitiveness and the consequence of its economic integration with mainland China. Viewed as such there is no short-term solution to Hong Kong's deflation. What Hong Kong can do is to mitigate the effects of deflation and seek ways through increased productivity to raise it competitiveness and speed up its economic recovery.

Efforts to speed up Hong Kong's recovery

The reliance on deflation for restoring Hong Kong's competitiveness is a painful process. Efforts must be made to speed up Hong Kong's economic recovery. Deflation is not only having its effects on prices and wages, it has brought about disastrous effects for property owners, business enterprises and also the government. Residential property prices have dropped by nearly $65 \%$ since 1997 . Many properties have become "negative assets" with their asset values much lower than their liabilities (the loans to the banks). Many people lost their jobs during the economic downturn and had to declare bankruptcy. Bankruptcy cases have increased in recent years.

Deflation has also caused hardship to business enterprises. With dropping demand on goods and services, it is increasingly difficult for business enterprises to maintain their profits. Share prices have dropped by half since 1997. With reduced profits many business enterprises have resorted to downsizing their operations, laying off staff and cutting wages. These explain for the high rate of unemployment in recent years ( $7 \%$ in 2002, see Figure 6)

Government revenue is also adversely affected by deflation. Due to a slow-down in economic activities, government revenue has decreased considerably. At the same time government expenditure on unemployment benefits have increased. These have led to the government facing substantial budget deficits in the past few years. In the last financial year (2002/3) the budget deficit reached more than HK\$70 billion being about $6 \%$ of Hong Kong's GDP.

Under the current conditions of service it is difficult for the government to cut the salary of civil servants in line with deflation. In the past when inflation took place the salaries of civil servants were adjusted upwards for inflation. However, there is no provision for downward adjustment of salaries when deflation takes place. In the last financial year (2002/3) the government was under heavy public pressure as well as budgetary need to cut civil service salaries, but faced strong opposition from civil servants. Eventually the government had to resort to an amendment of the relevant employment law so as to make the salary cut of $4.5 \%$ legal.

There is another difficulty for the government in respect of salary cuts. The Basic Law provides that the conditions of service of civil servants should not worsen after the handover of Hong Kong to China. This amounts to saying that the maximum salary cut 
in the future is a further cut of $6 \%$, reducing the salary level of civil servants back to 1997 levels. It has been announced recently by the government that an agreement has been reached between the government and the civil servants that salaries will be cut in two stages by a total of $6 \%$. The first cut of $3 \%$ will be effective from January 2004 and the second cut of another $3 \%$ will be effective from January 2005. It is estimated that the government can thus save HK\$7 billion per year.

Another problem similar in nature has occurred in the pricing policy of utilities such as electricity, gas and transport. In times of inflation, these companies had the right to apply for upward adjustment of charges to cope with inflation. In times of deflation, they naturally will not take the initiative to apply for a reduction in charges. There is no provision for the government to force these companies to reduce their charges. This surely generates unfairness for consumers, who have to bear the burden of salary cuts during deflation but cannot benefit from a reduction in charges. To tackle this problem the government is now trying to construct new formulae whereby such charges can be increased/decreased in line with inflation/deflation.

\section{Salary indices for managerial and professional employees}

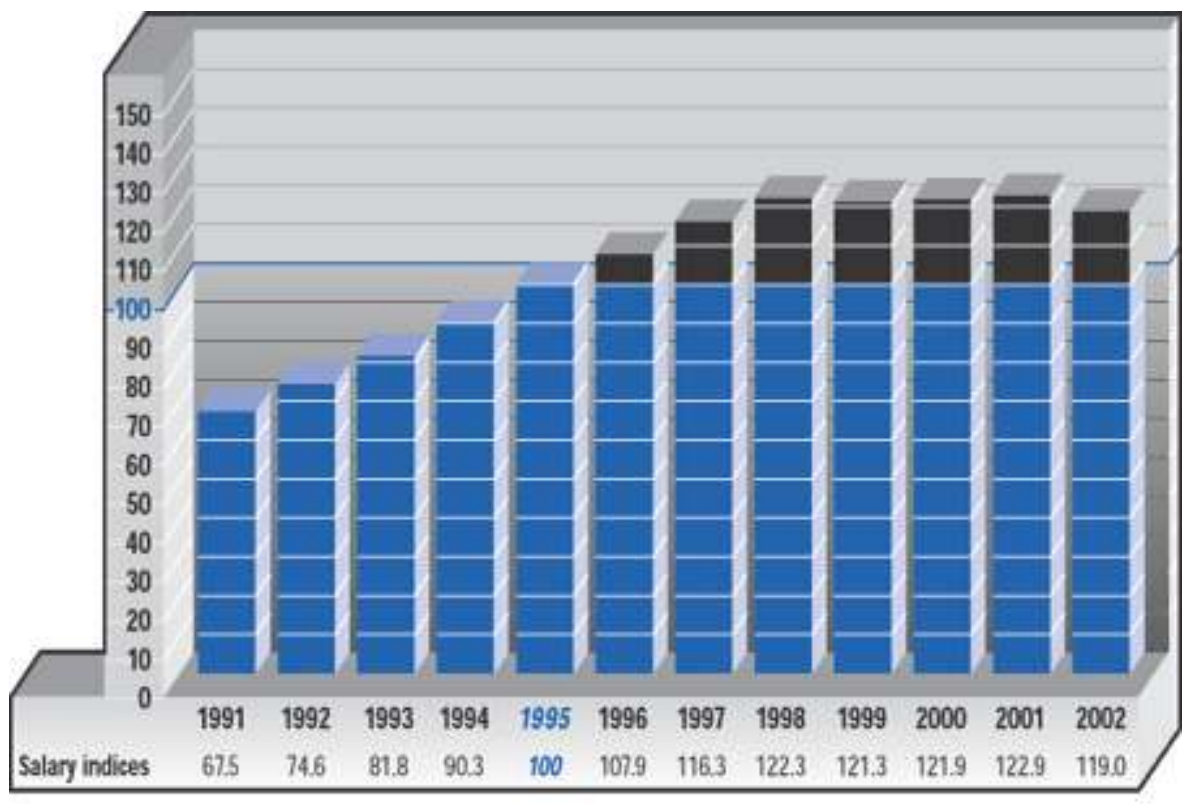

NB: These salary indices concern the major economic sectors following: manufacturing, electricity and gas; building and construction, and related trades; wholesale, retail and import/export trades; transport, storage and communications; financial institutions and insurance.

Figures for 2002 are preliminary estimates.

Source: Table 2.14, Hong Kong Annual Digest of Statistics, 2002.

At end of 2002 the government introduced measures to put a halt to falling property prices. These measures aimed mainly at reducing the supply of land. In times of falling property prices, buyers tend to postpone their purchases hoping to be able to buy at lower prices later. If there is a sign that property prices will not drop further, buyers will regain confidence and enter the market.

This, no doubt, is intervention by the government in the residential property market. Critics see the intervention as unnecessary as they think that the market will adjust by itself. They also see that if Hong Kong's price levels, including property prices and 
rents, can come down more quickly back to a level in line with economic fundamentals, economic recovery will take place sooner. However the view of the government is that property prices have fallen to an unreasonably low level due to people's loss of confidence in the property market, and that something must be done to put things in order. Moreover, the government has announced additional new measures to stimulate demand in the property market.

Despite the deflationary effects brought about by the economic integration between Hong Kong and mainland China, the government now regards more intense economic integration as a long-term strategy for maintaining Hong Kong's economic growth. This approach is reflected in the policy speech of Mr. Tung Chee-hwa, the Chief Executive of the Hong Kong Special Administration Region, delivered in January 2003. Mr. Tung identified more intense economic integration with mainland China, especially with the Pearl River Delta (PRD) region, as the most effective measure to speed up Hong Kong's economic growth ${ }^{11}$.

51 With the entry of China into the WTO, Hong Kong's importance as a middleman between mainland China and the outside world has diminished. Now mainland Chinese enterprises can deal directly with the outside world. So Hong Kong must find other ways to participate in China business. In its policy speech Mr. Tung identified certain areas where Hong Kong can be of benefit to China: logistics, financial services, business services and tourism. Excellence in these areas will maintain Hong Kong as an important city in the PRD region. Backed by the well-developed infrastructure, financial and judicial systems, it is hoped that Hong Kong will become the location where mainland Chinese companies as well as international companies will station their head offices.

What fiscal policy and monetary policy can Hong Kong employ to tackle deflation? As Hong Kong is in the linked rate system, there is no means of carrying out monetary policy. As to fiscal policy, there is not much that the government can do. As mentioned earlier, the government has run into heavy budget deficits in recent years. Instead of increasing its spending the government is now trying every means to cut its expenditure in order to balance its budget.

There have been proposals for the government to issue bonds to make up for the budget deficit and to adopt an expansionary fiscal policy. However the government is reluctant to do so. One major reason is that the successful operation of the linked rate system relies on the confidence of investors in the financial strength of the government. If confidence is lost as a result of the government incurring debts, substantial capital outflow will take place, which will cause systemic instability. As the government is still in possession of substantial budget reserves, it does not think there is an immediate need to issue bonds.

\section{Negative real interest rates}

\begin{tabular}{lrrrrrrrrrrrr} 
& 1991 & 1992 & 1993 & 1994 & 1995 & 1996 & 1997 & 1998 & 1999 & 2000 & 2001 & 2002 \\
\hline Interest rate (\%) & 6.21 & 3.89 & 3.39 & 4.76 & 6.17 & 5.46 & 7.12 & 8.06 & 5.84 & 6.11 & 3.56 & 1.79 \\
Inflation rate (\%) & 12.0 & 9.4 & 8.5 & 8.1 & 8.7 & 6.0 & 5.7 & 2.6 & -3.3 & -3.0 & -1.7 & -3.0 \\
Real interest rate $(\%)$ & -5.79 & -5.51 & -5.11 & -3.34 & -2.53 & -0.54 & 1.42 & 5.46 & 9.14 & 9.11 & 5.26 & 4.79
\end{tabular}

NB: Interest rate is represented by 3 months inter-bank rate. Figures for 2002 are preliminary estimates.

Sources: Table 10.15 and table 11.1, Hong Kong Annual Digest of Statistics, 2002. 

measures to improve its budget. (WHO), SARS has come under control.

However the issue can be viewed in another way. Issuing bonds does not necessarily mean the government financing its deficit through debt. It is a way to "buy time" to improve its budget position. With additional resources in hand the government can more effectively support the linked rate system in case it is disturbed by a sudden capital outflow. This, in turn, would raise confidence in the linked rate system. In the meantime, the government can have more time and flexibility to engineer its remedial

Economic recovery seemed to appear in the fourth quarter of 2002 as exports started to increase again. This trend continued in the first quarter of 2003. However, the outbreak of SARS (Severe Acute Respiratory Syndrome) in March 2003 practically brought the economic recovery of Hong Kong to a complete halt. The unemployment rate increased again, with the figure for May 2003 shooting up to $8.3 \%$. In spite of heavy budget deficits the government finds it necessary to put forth a rescue plan of about twelve billion HK dollars to stimulate domestic consumption. As a result of combined efforts by the government, the people of Hong Kong and the World Health Organisation

Hong Kong's economic problems are certainly of concern for the mainland Chinese government. Keeping Hong Kong prosperous economically after the handover is an important policy of the central government. One way to help Hong Kong out of the present economic problems is to allow Hong Kong more scope in participating in the economic development of Mainland China. In late June 2003, Premier Wen Jiabao, came to Hong Kong and chaired the signing of the so-called "Closer Economic Partnership Arrangement" (CEPA). The agreement grants zero tariffs to manufactured goods produced in Hong Kong. Also a number of professional services such as accountants, lawyers, architects, conference organisers, property agencies, etc. are allowed to run their own businesses in the mainland. It is expected that these privileges will help to provide job opportunities and to speed up Hong Kong's economic recovery.

The development of the external economic environment is also favourable to Hong Kong. Now that the Iraq war is over it is expected that the world economy will improve. Oil prices are expected to stay low, again providing conditions for world economy recovery. Increase in the growth of the world economy will then provide more export and re-export opportunities for Hong Kong. Furthermore the US dollar has recently weakened with beneficial effects on Hong Kong's exports under the linked rate system.

On July 1st 2003, half a million Hong Kong people took to the street protesting against the proposed anti-subversion law to be made in accordance with the provisions of Article 23 of the Basic Law. The issue has both political and economic implications. On the political front, Hong Kong people see the law as a threat to civil liberties. The law required Hong Kong to ban groups that are also outlawed in mainland China, to let security police conduct searches without warrants, and to bar exposure of China's state secrets without a public-interest defence. With the resignation of James Tien from Tung's Executive Council and Tien's declaration that he and his fellow political party members would not support the proposal of the law during Legislative Council debate, Tung had to announce postponement of the debate.

On the economic front, the great number of people taking to the street is due, not only to their aspiration for civil liberties, but to their dissatisfaction at the poor economic condition of Hong Kong. People are now unable to tolerate the high unemployment 
rate, the deflationary pressure, the loss of their property values, the proposed tax increases, and the proposed cuts in government expenditure. These sentiments were clearly shown in the slogans these people carried during the protest, such as "We need work opportunities", "Away with negative assets", "No more salary cuts" etc. So something needs to be done.

\section{The property bubble}

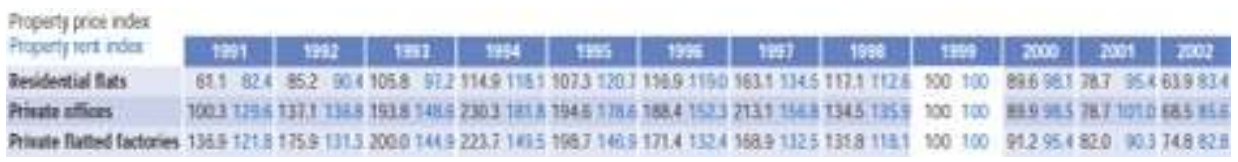

NB: Figures for 2002 are preliminary estimates.

Sources : Tables 7.15, 7.17 et 7.18, Hong Kong Annual Digest of Statistics, 2002.

The mainland Chinese government offered Hong Kong support. In early August 2003 the Hong Kong-Guangdong Co-operation Joint Conference was held in Hong Kong chaired by Mr. Tung Chee-hwa and Mr. Huang Huahua, the Guangdong province governor. Guangdong was to allow more people to travel to Hong Kong. Initially people of four cities, namely, Dongguan, Foshan, Jiangmen and Zhongshan, were allowed to travel to Hong Kong on an individual basis (previously they could only travel in tourist groups). The scheme would be carried out in stages until Guangdong's 75 million residents were allowed to visit Hong Kong on an individual basis starting from May 1st 2004. It was expected that the mainland tourist arrivals will hit 10 million a year when all of Guangdong's 75 million residents are allowed to visit Hong Kong on an individual basis. This is expected to bring into Hong Kong 50 billion dollars in consumption expenditure per year ${ }^{12}$.

61 Another encouraging achievement of the Joint Conference was the consensus between the Hong Kong government and the mainland government on the need to build a bridge linking Hong Kong, Zhuhai and Macau, the so-called Hong Kong, Zhuhai, Macau Bridge. The Joint Conference also considered other aspects of co-operation covering tourism, technology, culture, transport, intellectual property, trade, disease prevention, etc. As many as 15 sub-committees were set up to deal with these various aspects of co-operation. 


\section{Growing unemployment}

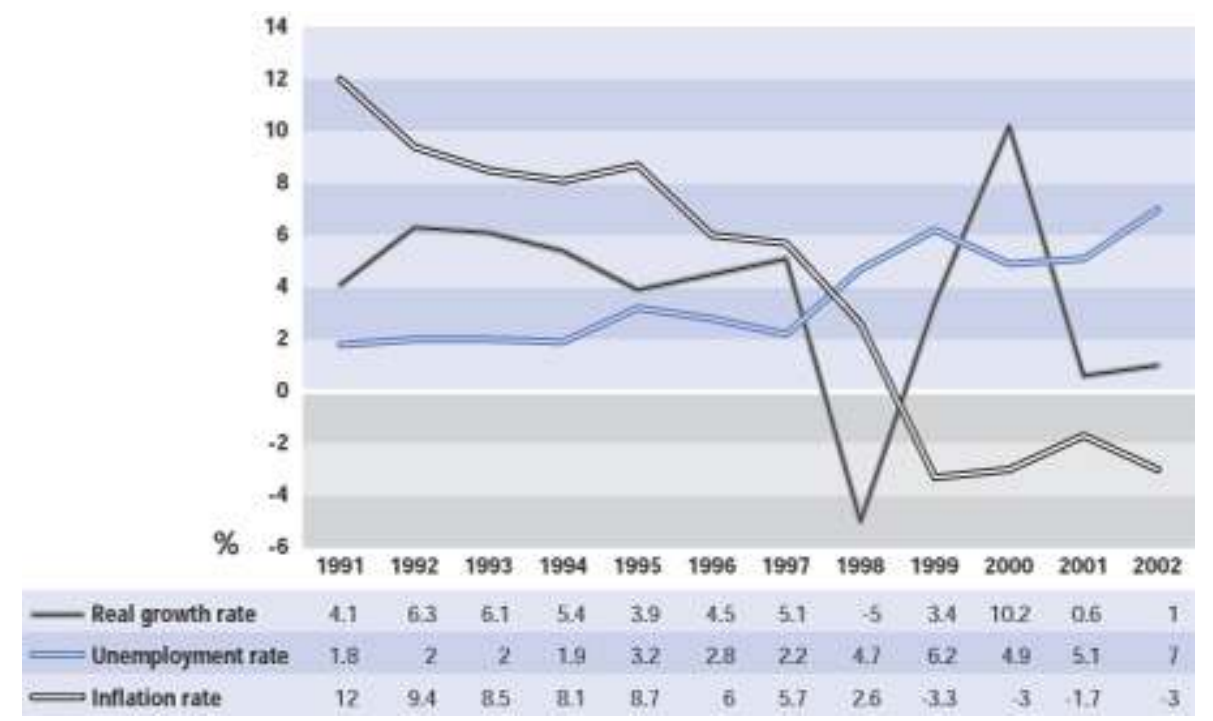

NB: Figures for 2002 are preliminary estimates.

Sources : Hong Kong Annual Digest of Statistics, Census and Statistics Department, Hong Kong Special Administrative Region, various years.

An important message conveyed by the Joint Conference is that both governments would adopt a new approach in its co-operation efforts. Much stress has been made on developing Guangdong as a manufacturing base and Hong Kong as a logistics, business and financial centre in the PRD region. So instead of competing between themselves in various areas, division of labour becomes the main theme. This is a break through in thinking, implying that Guangdong and Hong Kong are no longer two individual economic territories, but both submerging into one economic zone.

the Joint Conference was of far-reaching significance. Not only had it taken a step towards building the link between Hong Kong and western Guangdong with the bridge proposal, it also marked the beginning of a new era in cross-border cooperation. By announcing plans to turn the PRD region into an "economic super-zone" both Hong Kong and Guangdong would benefit. Guangdong was to speed up its economic development while Hong Kong would achieve its economic recovery ${ }^{13}$.

Hong Kong's inflation in the early 1990s and Hong Kong's deflation after the Asian financial turmoil have much to do with the linked rate system. Inflation and deflation are adjustment mechanisms for when the economy is out of line with its economic fundamentals but without the possibility of revaluation and devaluation of the currency.

65 In the early 1990s Hong Kong experienced high inflation. The two major causes for Hong Kong's inflation in the early 1990s were an over-heated economy and structural change. Under the linked rate system it is not possible to revalue the HK dollar to cope with inflation. Inflation itself, however, serves as an adjustment mechanism. Inflation reduces Hong Kong's competitiveness and slows down export growth. The resulting contractionary effect on the economy slows down inflation.

After the Asian financial crisis, Hong Kong experienced deflation. The two major causes for Hong Kong's deflation are sluggish demand and economic integration between Hong Kong and mainland China. Under the linked rate system it is not possible to 
devalue the Hong Kong dollar to cope with deflation. Deflation itself, however, serves as an adjustment mechanism. Deflation enables Hong Kong to regain its competitiveness and to achieve economic recovery.

Although deflation serves as an adjustment mechanism for Hong Kong's economy, it is a painful process. Measures are needed to mitigate the effects of deflation. However it is found that for Hong Kong being a small open economy the scope for macroeconomic policies, i.e. fiscal and monetary policies is limited.

A more practical approach for tackling deflation is to foster more intense economic integration between Hong Kong and mainland China. It is hoped that through participating more closely in the economic development of mainland China Hong Kong can grasp the business opportunities available there, especially now that China has gained entry into the WTO.

Logistics, financial services, business services and tourism have been identified as the key areas where Hong Kong should concentrate its efforts and allow resources to develop. These are the areas where Hong Kong can play important roles in the economic development of China, especially in the PRD region. It is expected that Hong Kong can remain a major commercial and financial centre in the PRD region.

There has been a fundamental change of attitude of the Chinese mainland government with regard to the economic development in the PRD region. Instead of giving a free hand to the Guangdong cities to compete with Hong Kong, they are now being led to cooperate with Hong Kong closely through a greater division of labour. Hong Kong is to position itself as a "front shop" while the Guangdong cities will position themselves as "manufacturing support at the back". Hong Kong and the Guangdong cities are expected to make up an economic upper-zone.

\section{NOTES}

1. For a detailed explanation of the operation of the linked rate system see Joseph Yam, "The Hong Kong Dollar Link", Quarterly Bulletin, Hong Kong Monetary Authority (HKMA), May 1998, pp. 45-59.

2. John Greenwood, "Advantage of the Current Linked Rate System for the Hong Kong Dollar: A Restatement”, HKCER Letters, Hong Kong Centre for Economic Research, May 1991, pp. 1-4.

3. The real interest rate is the interest rate adjusted for inflation. For example if the interest rate is $6 \%$ and inflation $2 \%$, then the real interest rate is $4 \%$. The real interest rate reflects the real cost of borrowing.

4. See Peter Chiu, "Tantao gangyuan yu yilanzi huobi guadiao hou huijia de bianfa", (An analysis into the possible change of exchange rates after pegging the Hong Kong dollar with a basket of foreign currencies), Xinbao caijing yuekan (Hong Kong Economic Journal Monthly), March 1988, pp. 38-41.

5. See Peter Chiu, "The Linked Rate System and Monetary Stability: The Views of the Hong Kong Monetary Authority", Asian Profile, Vol. 31, No. 1, February 2003, pp. 15-27. 
6. Tony Latter, “Challenges for Exchange Rate Policy”, Quarterly Bulletin, HKMA, August 2001, pp. 33-36.

7. Tony Latter, “Hong Kong Currency Board Today: The Unexpected Challenge of Deflation", Quarterly Bulletin, HKMA, August 2002, pp. 48-53.

8. See Peter Chiu, "Economic Integration between Hong Kong and Mainland China", China Perspectives, No. 40, March-April, 2002, pp. 62-71.

9. For an account of the theorem, see P. A. Samuelson, "International Trade and the Equalization of Factor Prices", Economic Journal, Vol. 58, 1948, pp. 165-84.

10. Joseph Yam, "Deflationary Pressures on Hong Kong”, press release from the government of Hong Kong, September 20th 2001. (http://www.info.gov.hk/hkma/eng/ viewpt/20020920.htm).

11. See Policy Speech by Mr. Tung Chee-hwa, the Chief Executive of the Hong Kong Special Administration Region, in the Legislation Council of Hong Kong on January 8th 2003, published by the Hong Kong Government.

12. Carrie Chan, "Mainland tourist arrivals to hit 10m.", South China Morning Post, August 6th 2003, p. A3.

13. Chris Yeung, "Leaders' pragmatism clears the way for an economic super-zone", South China Morning Post, August 6th 2003, p. A3.

INDEX

Thèmes : economie 